\title{
Energy efficiency in an integrated agro- ecosystem within an acidic soil area of the Mekong Delta, Vietnam
}

\author{
Nguyen Thi Thu Thao ${ }^{1,2}$, Tra Van Tung ${ }^{1}$, Nguyen Thi Phuong Thao', Son Le Thanh" ${ }^{4}$, Sibylle Braunegg ${ }^{6}$, \\ Gerhart Braunegg ${ }^{5}$, Hans Schnitzer ${ }^{3}$ and Le Thanh Hai ${ }^{1 *}$ (D)
}

\begin{abstract}
Background: Both exergy and energy analysis methodologies are used for analysing energy efficiencies in various processes, including agriculture. This study focuses on the connection of three main process components (husbandrycrop-fishpond) in a typical farming household located within an acid soil region of rural Vietnam. The concept of exergy analysis is used to underline the potential for resource efficiency in alternative processes in the agricultural system. For development of an integrated ecological system aiming towards zero emissions, the analytical methods of material cycles and energy flows utilized a set of indicators of resource efficiency in a sustainable agriculture.

Results: The design of the ideal integrated farming system "Agro-Industrial Zero Emissions Systems" (AIZES) can increase the system efficiency by making use of indigenous natural materials and waste reuse/recycling. Recycling waste produce energy, fish feed and fertilizer can result in a decreased environmental load of approximately half. Using exergy analysis to calculate an indicator non-renewable yield ratio (NRYR), the systems verified sustainability of agriculture production.

Conclusions: The farming household will be able to subsidize their fuel and electricity consumption by utilizing biogas. Surplus biogas will be distributed to proximate households, further creating sustainable goals. Biochar, created by mixing the biomass residues with local plants, will improve soil quality and pig sludge, mixed with biomass residue, will create highquality fertilizer.
\end{abstract}

Keywords: Agricultural system, Acid sulphate soil, Biogas, Exergy efficiency, Zero emissions

\section{Introduction}

Integrated biosystems connect all functional components in a system such as agriculture, aquaculture, waste treatment, fuel and water use [1]. Waste and by-products in these systems become inputs for an additional process step, closing the cycle of all material flows. The study of Huong et al. provides good perspectives for integrated biosystems like the combined orchard-fishpond-livestock system operated in Vietnam [2]. Reduction of waste

\footnotetext{
* Correspondence: haile3367@yahoo.com

'Institute for Environment and Resources, National University of Ho Chi Minh City, Ho Chi Minh 740500, Vietnam

Full list of author information is available at the end of the article
}

implies an effective decrease in energy demand in agricultural systems and thus encourages proper energy optimization approaches for evaluating systematic energy efficiencies. In order to calculate energy analyses for agriculture utilizing a standard energy unit, this evaluation focuses on the energy conversion of all materials. Some European countries report energy saving measures categorized by subsectors of agriculture, then divide production energy inputs into indirect energy (inorganic fertilizers, pesticides) and direct energy (fuels and electricity) [3]. To define energy saving potential for implementation in an agricultural production, two approaches can be considered: applying new energy 
technology(ies) or improving existing energy efficiency(ies) $[3,4]$.

Vigne et al. collected many references of diverse agricultural systems to assess the energy use [5]. The review shows that production of livestock is usually much less energy efficient than fruit or crop production. Livestock systems are reaching $1 \mathrm{MJ}$ of nutrition energy per $1 \mathrm{MJ}$ of non-renewable energy, while fruit, vegetables or crop can achieve 5-15 MJ per $1 \mathrm{MJ}$ of non-renewable energy. The study also shows that energy analysis, independent of entire energy sources, is a proper way to develop energy use effectiveness.

Biogas digestion is one of the best methods for supplementing energy supply in agricultural systems since biowaste is readily generated [6]. However, there are only a few publications investigating the integrated system of agriculture and biogas. In Germany, family farms use biogas plants as an important economic sector for rural sustainable development [7]. Biogas, as a renewable energy source, can be a supplement for other fossil fuels popular in rural areas [8-10]. A study of Yang and Chen [11] shows the experiences of energy analysis linking agricultural and biogas systems. The study was conducted in Gongcheng Yao Autonomous County, China, assessing energy balance through the performance of biogas engineering in a compound agricultural system. Zhang and Wang [12], additionally, carried out research on biogas at a typical household scale in a rural region in China. The main indicator used for the energy analysis was the energy return on energy investment (EROI). EROI is the ratio of the amount of energy obtained from an energy resource compared to the amount of energy expended to produce that energy resource. The study of Perryman et al. [13] indicated that the EROI concept has been applied for a long time.

The comparison of energy use versus energy efficiency in organic and conventional farming systems shows that organic agriculture with its sustainable production methods can be more efficient in energy utilization in e.g. livestock and ruminant production systems [14]. An evaluation of system effectiveness of biomass feedstock is represented in the paper of Wightman and Woodbury [15] and of Maier et al. [16]. By analysing the energy conversion of raw inputs and the final energy services and assessing the energy returned on investment, this method provides an holistic approach to the land unit value for sustainably producing primary energy resources [15].

Exergy analyses evaluate the maximum useful work possible during a process that brings the system into equilibrium with a heat reservoir (typically, in a defined environment). The exergy reflects the resource consumption which is embedded to the input flows in the ecological processes and products or services under the equilibrium conditions of environment [17]. An exergy ecosystem analysis was conducted in a conventional semi-natural cropland in China. Cosmic exergy accounting was applied for evaluating three agro-ecosystems comprising all, or a mixture of, farmland, biogas and dairy [18]. The study better defines relationships between energy conversion and information exchange in ecological flow. Additionally, it suggests an extended exergy approach which is suitable for evaluation of sustainability potential.

Exergy analysis is applied for improving the framework of exergy-based natural resource measures for sustainability of agricultural production via computation of a cumulative overall natural resource efficiency (COREA) in the agricultural context [19]. Eco-exergy, a form of exergy, computes qualities of biomass in ecosystems. Eco-exergy of organisms or ecosystems is defined as the work energy embodied in the information. It has adopted a wide systematic range of ecosystems (e.g. forests) to social system (e.g. cities) excluding particular species and various economic aspects [13, 20]. Rarely has eco-exergy been applied to evaluations and comparison of biomass recycling in a system [21]. The present study has been established to evaluate a closed scheme for integrated eco-agriculture systems based on the exergy analysis and energy analysis. This allows analysts to estimate potentials for sustainable developments of ecosystems. When recovering energy from waste, extended exergy accounting (EEA) is an appropriate analysis technique to quantify problems that stem from monetary or thermo-economic approaches. This study offered the application of EEA to a technical alternative evaluation for recycling of non-integrated waste, integrated waste, and an incineration facility [22].

The agricultural system in rural Vietnam is dispersed and typically developed at a small scale; therefore, resource efficiency in terms of a systematic consideration of input-output flows is not a significant consideration. Livelihoods in south-west rural regions mostly depend on agriculture. It is necessary to take the loss of resources in farming processes into account. Economic and environmental aspects of the farming by-products and biomass residues are not likely to be reused but largely discharged. The local conditions of the acid sulphate soil cause difficulties in the production for aqua-agro culture because of low soil and watershed $\mathrm{pH}$ levels, ranging from 4 to 5 . This results in a lack of water that is safe enough for plant irrigation on a production scale. Hence, the utilization of indigenous plants, adapted to the special conditions of acid soil, associated with the reuse of waste will be able to maximize the production efficiency. According to Taheri et al. [23] an exergy analysis incorporating both exergy efficiency and exergy destruction underlines the ineffective energy use in alternative processes. Inefficiencies in energy loss, as 
heat, and emissions occur through the irreversibility within the process to the environment. The considerable amount of energy losses represent extra unexpected costs for energy purchase and detrimental environmental side effects [24]. Indicators of comprehensive energy evaluation may include energy efficiency, exergy efficiency and exergy destruction [23]. Exergy and energy analysis methods are basically used in analysis and comparison of energy in intensive manufacturing processes. Thermodynamic methodologies manifest energy efficiency evaluation in manufacturing processes, implying exergy as well as energy balance [13, 18, 19, 21, 23, 25]. Agricultural waste contributions need to be accurately identified in order to calculate actual losses and to consider potential of waste recycling during the farming process. By the first law of thermodynamics, energy is always conserved in the system but can be transported over the systems boundaries [24].

Based on the exergy efficiency analysis (i.e. exergy calculation), the objective of the paper is to assess the utilization of materials derived from the system process (i.e. heat and waste) in energy forms, which is wastefully disposed. Exergy analysis estimates the sustainable potential of a closed eco-agro system under the specific conditions of the local agricultural environment in acid soil area in Vietnam. Thereby, exergy loss from the system can be computed in the same unit of energy (Joules); whereas it cannot be counted in physical units. Indicators were developed from exergy analysis to evaluate the efficiency of conversing materials flows into energy in biogas-linked agricultural systems [11, 21, 25]. Liu et al. [21] suggested that the exergy efficiency is highly prior to the system of a big ecosystem scale which consists of three elements, farming, dairy and biogas. Exergy and indicator evaluation was assessed during the sustainable agricultural development in China between 2001 and 2015 [26]. The results showed reduced consumption of natural resources as well as decreased purchase of non-renewable resources (versus agricultural yields).

A proposed closed loop scenario of the total agroecosystem is proposed. This shall be estimated through exergy efficiency calculations based on waste utilization and supplements to the local ecosystem. Additionally, potential flows of input-output (towards zero emissions) shall be considered for improving the agricultural system.

\section{Methodology}

\section{Conceptual framework}

The conceptual framework of the study is presented in Fig. 1. The study approach is based on the integration of resources in agriculture to create a closed ecological system, which is aimed at optimizing the efficiency of materials and energy use, i.e. maximizing the use of renewable energy resources and minimizing nonrenewable resources [27]. Utilization of waste and material flow recycling is proposed for creation of a zero emission system. "Zero emission" means that no waste is likely to cause environmental pollution. In agriculturebased rural areas, main living activities consist of crop cultivation (or horticulture), aquaculture and livestock. The scale of household farming varies, commonly showing a combination of functional components such as crop-fishpond and animal husbandry-crop. The research subject is a system of all three main components (husbandry-crop-fishpond). The design of an integrated farming system can increase the system efficiency minimizing the input of non-renewable resources. Making use of indigenous natural materials available on the farm will minimize the cost as well as the consumption of transportation fuel. Waste utilization or recirculation is considered a production unit in the system when waste or by-products are converted into inputs within the system. By this approach, the use of non-renewable materials will be reduced enhancing system sustainability [28].

Considering integrated systems from peer literatures regarding the living conditions of the household, an agro-based industrial zero emissions systems (AIZES) is proposed. It is an eco-agro-linked system composed of functional components, i.e. orchard (O)-fishpond (F)animal shed (S)-biogas digester (D)-housing (H)-plant (P)-waste treatment (T)-ecosystem (E) (as defined below and as presented in Fig. 1). This model by Le et al. was developed to achieve zero emission in agriculture and contribute to sustainable livelihoods for farmers in the Mekong Delta [29]. It is derived from the typical model of agriculture-fishpond-livestock-biogas system. Other components maybe integrated to the system, such as a wastewater treatment system, available natural resources available, soils and human activities with management functions. These components, playing a very important role in material cycles, solve environmental pollution problems from waste and can create profit for farmers. The functions of the components in the system are described as follows (Fig. 1):

- O (orchard) takes up products from two components S and F. Raw materials like dry leaves from trees and other plants from the local ecosystem (component E) are used for composting and biochar production (component F).

- F (fishpond) serves as nutrient storage receiving input from $\mathrm{D}$, and its water can be used to irrigate the orchard (component $\mathrm{O}$ ).

- $S$ (animal shed) receives feeding from component $O$ and produces waste (manure and urine), which is the main source for components $\mathrm{F}$ and $\mathrm{D}$. 


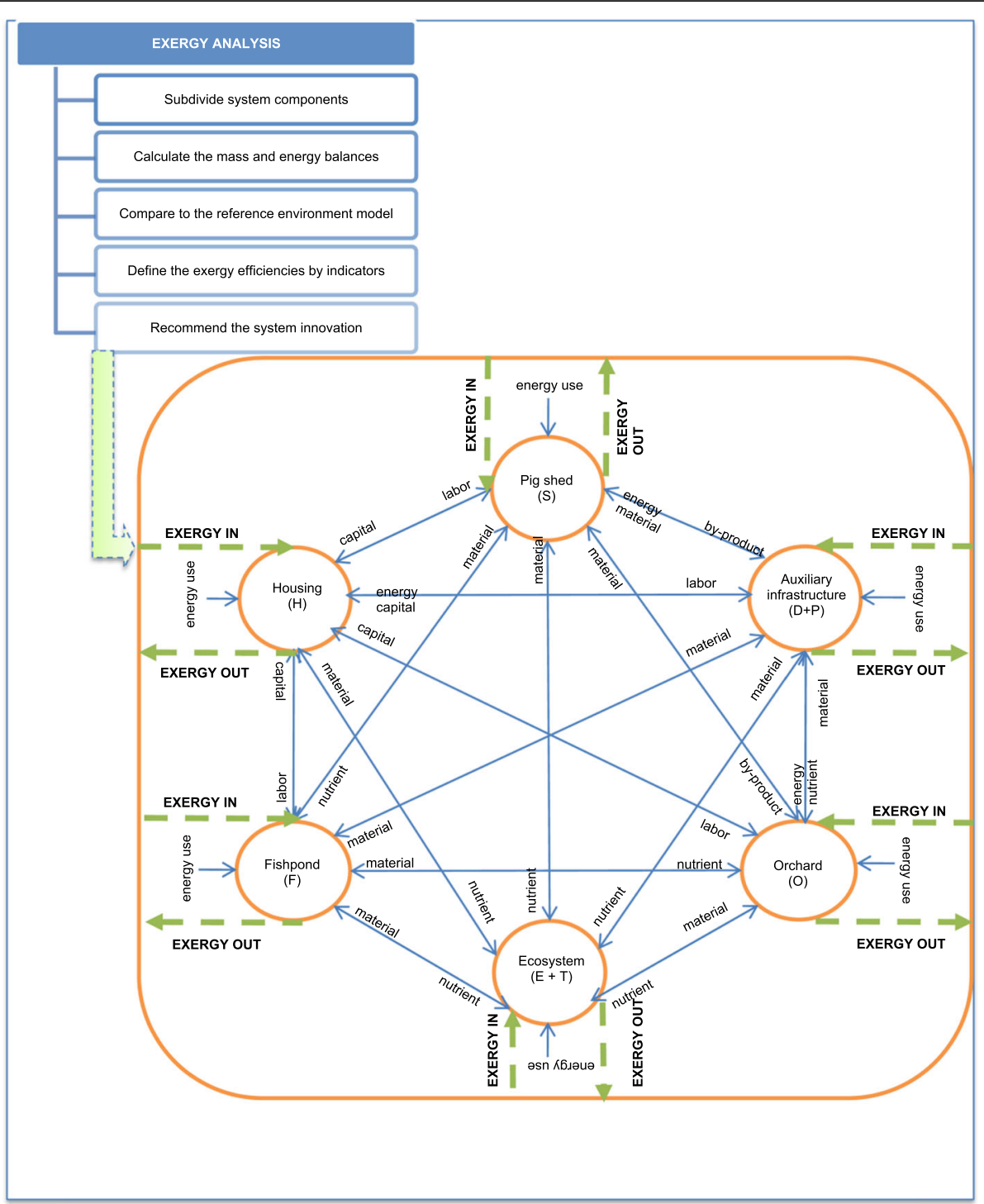

Fig. 1 Conceptual framework for energy conservation in an integrated farming system

- D (biogas digester) converts carbon- and nitrogenrich waste from black water into bioenergy $\left(\mathrm{CH}_{4}\right)$. It transforms sediments from the fishpond and livestock manure from the components $\mathrm{F}$ and $\mathrm{S}$ to compost used as an organic fertilizer for component $\mathrm{O}$.

- $\mathrm{H}$ (housing) plays the key role in controlling and managing all system activities and is directly affected by the outputs. It consumes energy converted from the biogas of D (heat and electricity). In addition, it gains benefits from the other system activities.

- P (composting-biochar plant) transforms dry leaves from component $\mathrm{O}$, sludge from the biogas digester and the locally available plants from components $\mathrm{D}$ and $\mathrm{E}$ into compost and biochar to re-supply components $\mathrm{O}$ and $\mathrm{T}$.
- $\mathrm{T}$ (waste treatment system) is used to treat wastewater from $\mathrm{D}$ and $\mathrm{S}$ using aquatic plants such as water spinach (Ipomoea aquatica) and water hyacinth (Eichhornia crassipes) from component $\mathrm{E}$ and biochar (component P). After the treatment, the water from the fishpond can directly be used for irrigation of the orchard $\mathrm{O}$. The biogas effluent treated by biochar filtration is reused to irrigate the crop (component $\mathrm{O}$ ), and after completing adsorption, the biochar will be recovered and reapplied in the system for component $\mathrm{O}$ as a source of nutrients.

- E (native ecosystem), the land with naturally growing native plants such as spinach, water hyacinth and vegetables is the place where organic 
matter accumulates. It serves as additional organic fertilizer for $\mathrm{O}$ and $\mathrm{F}$ to improve the soil properties. It receives compost from component $\mathrm{P}$ storing and metabolizing the nutrients for subsequent crops.

Analysis of energy savings must take into account input alternatives for optimum reduction of energy losses. To calculate the overall system efficiency including the existing mass and energy balances, the exergy concept can be a quantifier for material flows in one common unit (joules of exergy) [18]. Input flows to the system are computed in the form of energy flows to assess the efficiency of processes through calculations of both accumulated energy and accumulated energy loss. The analytical method known as "exergy analysis" focuses primarily on evaluating the resource efficiency indicators of the input and output flows in energy form. In particular, the inputs and outputs of each component in the integrated system are quantified. To develop an integrated ecological system with potential for zero emissions, the analytical methods of material cycles and energy flows shall use a set of indicators to evaluate resource efficiency in sustainable agriculture. The total exergy efficiency is evaluated through these indicators to optimize the selection of alternatives for sustainable farming system [11, 21, 25]. The system with maximum utilization of bio-waste and by-products from biogas, crop production and livestock systems, particularly using local materials as a supplement within the agricultural system, can improve a sustainable livestock and crop production systems $[11,30]$.

Physical boundaries of the entire system must encompass a proper size for the analysis of a process [31]. The extension portion of the surrounding environment including both materials and energy, which are extracted to the system processes, may be quantified. Figure 2 shows the boundary size of the studied farming system including the combination of productive components.

Studying the boundary of the system takes the following key factors into account: biogenic flows, water flows, chemical flows, energy flows and the system sustainability [18]. It is important to also consider temporal interactions between the performance of components [32] and the chronological sequences in the system since components of agriculture vary in productive timespan.

\section{Exergy analysis}

A comprehensive exergy analysis of a system has to be performed following the simple procedure shown below [33]:

- The systematic process has to be subdivided into expectably manageable system components (process or sub-process).

- The mass and energy flows of the process must be identified, and the balances must be calculated in terms of basic quantities and properties.

- A reference environment model must be chosen to obtain an acceptable analysis complexity and accuracy levels including a quantification of energy and exergy values.

- The exergy balances related to energy consumptions must be calculated.

- The energy and exergy efficiencies based on the proper measures of merits must be defined.

- Appropriate conclusions related to the evaluation of each system component are drawn and a system innovation is recommended.

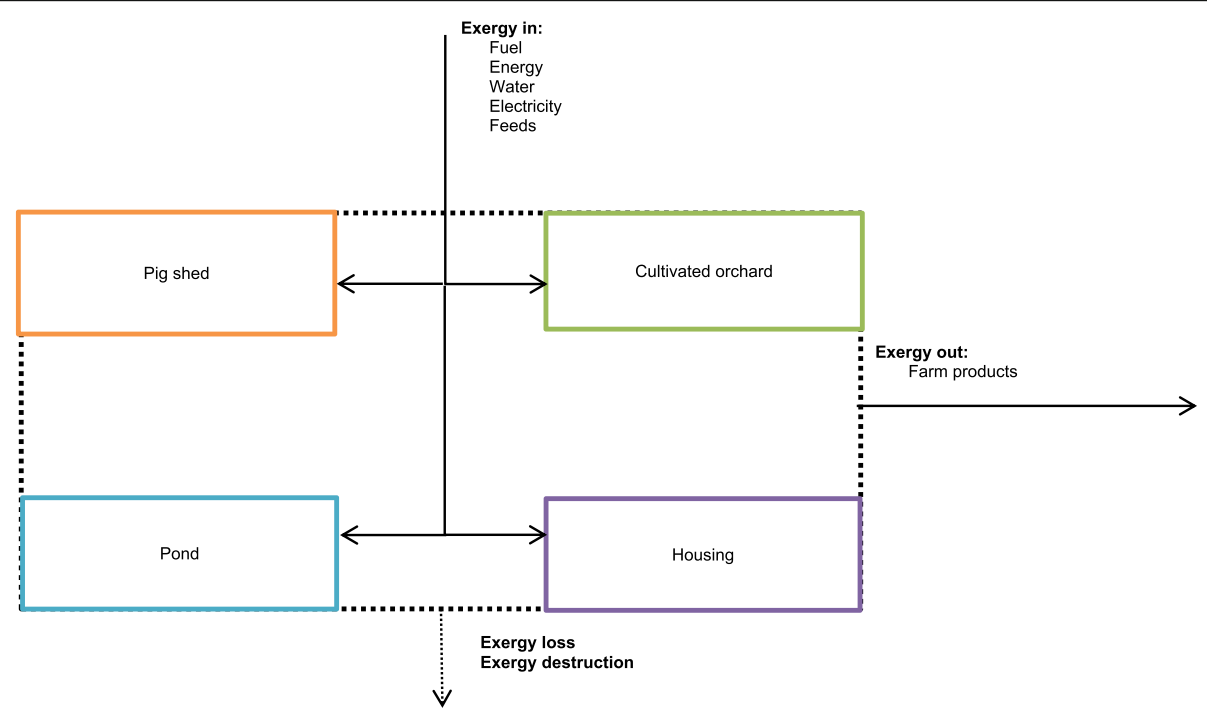

Fig. 2 Boundaries of the current agricultural system 
The exergy concept can be a quantifier for material flows in one common unit (joules of exergy). Exergy uses thermodynamic metrics to assess material flows extracted from the system process [17]. Due to the low quality of resources in the subsequent transformation step, exergy analysis considers both the quality and the quantity of resources on one single scale. The ratio of yields (products) and inputs implies the exergy efficiency $\eta$ of the process [18]. Exergy analysis (EA) considers a system or process for the balance of all inputs and outputs in unit of exergy content per time (i.e. J/year) to evaluate the exergy efficiency $(\eta)$ which is a fraction of the desired product to the input exergy [19].

$$
\eta(\%)=100 \times \frac{\text { exergy outputs (products) }}{\text { exergy inputs }}
$$

For the exergy efficiency of product and by-products, it implies $\eta^{\prime}$.

$$
\eta^{\prime}(\%)=100 \times \frac{\text { exergy outputs (products and by }- \text { products) }}{\text { exergy inputs }}
$$

The method of analysing and evaluating input and output streams was used for the presented paper. We adapted a type of network modelling method [21] of energy interaction of the whole goods and services via the statistics of total intermediate inputs and organization matrices. The energy transactions in a basic EA framework perform the flow of resources for each component of eco-agriculture system as a producer. EA uses a onestep conversion procedure to transform physical units of energy inputs of the system via conversion factors (called "energy coefficients") into total fossil energy [5]. According to Taheri et al. [23] the higher the temperature in the system process, the smaller the exergy destruction; hence, an energy efficiency evaluation would not be much different compared to the evaluation of exergy efficiency. In addition to quantifying exergy efficiency and exergy destruction, the increased process timespan leads to magnifying the exergy destruction value. Exergy efficiency plays an important role in the outcome analysis of the process. Exergy analysis accounts for exergy loss and the process efficiency $(\eta)$ for a certain time (a year) due to a steady state; the exergy balance is calculated as follows [19, 34]:

$$
\begin{aligned}
& E_{\text {in }}=E_{\text {out }}+E_{\text {loss }} \\
& \eta(\%)=100 \times \frac{E_{\text {out }}}{E_{\text {in }}}=100 \times \frac{E_{\text {in }}-E_{\text {loss }}}{E_{\text {in }}}
\end{aligned}
$$

$E_{\text {loss }}$ represents the waste or by-products exergy or the output streams represented by exergy unit divided by time that contrasts with exergy destruction due to the recovery characteristics.

For an exergy analysis, both exergy destruction (irreversible within the process, not serviceable for work, and should possibly be eliminated) and the exergy losses to the environment are computed.

$$
\begin{aligned}
& E_{\text {in }}=E_{\text {out }}+E_{\text {loss }}+E_{\text {des }} \\
& \psi=\frac{E_{\text {out }}}{E_{\text {in }}}=1-\frac{E_{\text {loss }}+E_{\text {des }}}{E_{\text {in }}}
\end{aligned}
$$

The performance of exergy efficiency $(\psi)$ is better in comparison with efficiency $(\eta)$ [23]. The loss refers to the by-products or wastes, which actually or potentially cause pollution contrasting with the destruction due to its attribute of recovering. The destruction refers to the amount of exergy that is irreversible emissions. Then, cumulative exergy consists of cumulative loss and cumulative destruction.

Sciubba [35] represents exergy algebra for efficiency and cost calculations that the outputs consist $[O]$ of the desired product $(O 1)$, of some energy rejection to the environment $(\mathrm{O} 2)$, of a by-product $(\mathrm{O} 3)$ and of some waste $(O 4)$.

$$
E o=\pi E i=\pi\left|\begin{array}{c}
E i 1 \\
E i 2 \\
\ldots \\
E i k
\end{array}\right|=\left|\begin{array}{c}
E o 1 \\
E o 2 \\
\ldots \\
E o 4
\end{array}\right|
$$

The internal transfer function of a process (i.e. each component in the system) linking the outputs with the inputs is called conversion efficiency or transformity unit. This study selects a number of energy conversion coefficients (or equivalent factors) of research literature, which are suitable to local conditions for the calculation of embodied exergy in agricultural systems.

In general, the efficiency of systematic farming process is analysed in an exergetic concept referring to the sustainability of agriculture, which is defined by the set of indicators of sustainable agriculture employed in this study (Table 1) [25]. Renewability Index (RI) implies the role of renewable resources in the total resources. Environmental loading of investment (ELI) indicates that the environment will suffers if the ELI value is high. Investment-yield ratio (IYR) presents the ratio of purchased resources to the expected outputs. Ecosystem resource-yield ratio (ERYR) reflects the contribution of ecosystem resources in producing the outputs or producing yields $(\mathrm{Y})$. System transformity $(\mathrm{STr})$ is the ratio of the total inputs to the outputs. It suggests that the higher system sustainability means the lower STr. Nonrenewable yield ratio (NRYR) estimates how much effectiveness of the system production depending on the non-renewable resources. Three basic resources are 
Table 1 Indicators of exergy efficiency for sustainable agriculture (adapted from [25])

\begin{tabular}{|c|c|c|c|}
\hline Indicators & Implication & Equation & Trend \\
\hline $\mathrm{Rl}$ & Renewability Index & $\mathrm{Rl}=(\mathrm{RR} /(\mathrm{RR}+\mathrm{NR}+\mathrm{PN}))$ & $\checkmark$ \\
\hline ELI & Environmental loading of investment & $E L I=(P N /(R R+N R))$ & $x$ \\
\hline IYR & Investment-yield ratio & $I Y R=P N / Y$ & $x$ \\
\hline ERYR & Ecosystem resource-yield ratio & $E R Y R=((R R+N R) / Y)$ & $\checkmark$ \\
\hline $\mathrm{STr}$ & System transformity & $\mathrm{STr}=(\mathrm{RR}+\mathrm{NR}+\mathrm{PN}) / \mathrm{Y}$ & $x$ \\
\hline NRYR & Non-renewable yield ratio & $N R Y R=(N R+P N) / Y$ & $x$ \\
\hline
\end{tabular}

" $\checkmark$ " indicates higher is better and " $\mathrm{X}$ " indicate lower is better

natural renewable resources (RR), non-renewable resources (NR) and purchased non-renewable (PN) resources. In the extent of the study, purchased-renewable resources (PR) (i.e. human labour) are not taken account. Labour can be attributed to PR when householder has to hire labour power [25]. It is also renewable resource (RR) in the case of the current study area. The majority of human labour (20 people) is household family members; hence, there is no cost.

\section{Results and discussion Case study description}

Experiments in this study were carried out at a farm household of 8.1 ha of land use for farming in Long An Province $\left(10^{\circ} 36^{\prime} 24^{\prime \prime} \mathrm{N}, 106^{\circ} 8^{\prime} 31^{\prime \prime} \mathrm{W}\right)$. The local weather conditions show an average temperature of $27^{\circ} \mathrm{C}$ and an average annual amount of evapotranspiration of up to $2000 \mathrm{~mm}$. There are three productive components in the operation of the farm: pig farming, fish breeding and orchard operations. The farm raises piglets for pork production at an industrial scale $(\sim 4500$ heads of pig). The total shed area is $1800 \mathrm{~m}^{2}$. Jackfruit trees
(Artocarpus heterophyllus) are planted with a density of 525 trees per ha (over approximately $2.5 \mathrm{ha}$ ). Pig and fish feed and fertilizer are commercially sourced. For the fishponds, covering approximately 5 ha, river water (augmented with lime) is utilized to ensure the $\mathrm{pH}$ ranges between 6.5 and 8 for the farmed fish. Similarly, river water (also lime adjusted) issued to irrigate the orchard. Hence, about $180 \mathrm{~m}^{3}$ water per day from the well are used for both living and breeding. Wastewater from the pig farm, including pig manure and washing water, is directly discharged into internal ditches and then discharged into field canals. The monthly electricity consumption equates to approximately $12,000 \mathrm{kWh}(43,200$ MJ) - generally attributed to washing pigs, ventilating fans, pumping water and human activities. Two dieselfired generators are used to create the nominal electrical demand of $27 \mathrm{~kW}$, consuming approximately 61 fuel $/ \mathrm{h}$.

The entire system with all material flows embodied in a typical agricultural system in the acid soil area in Vietnam is presented in Fig. 3. The natural renewable resources serving for the whole production system include sunlight, wind, rain, surface water, and soil.

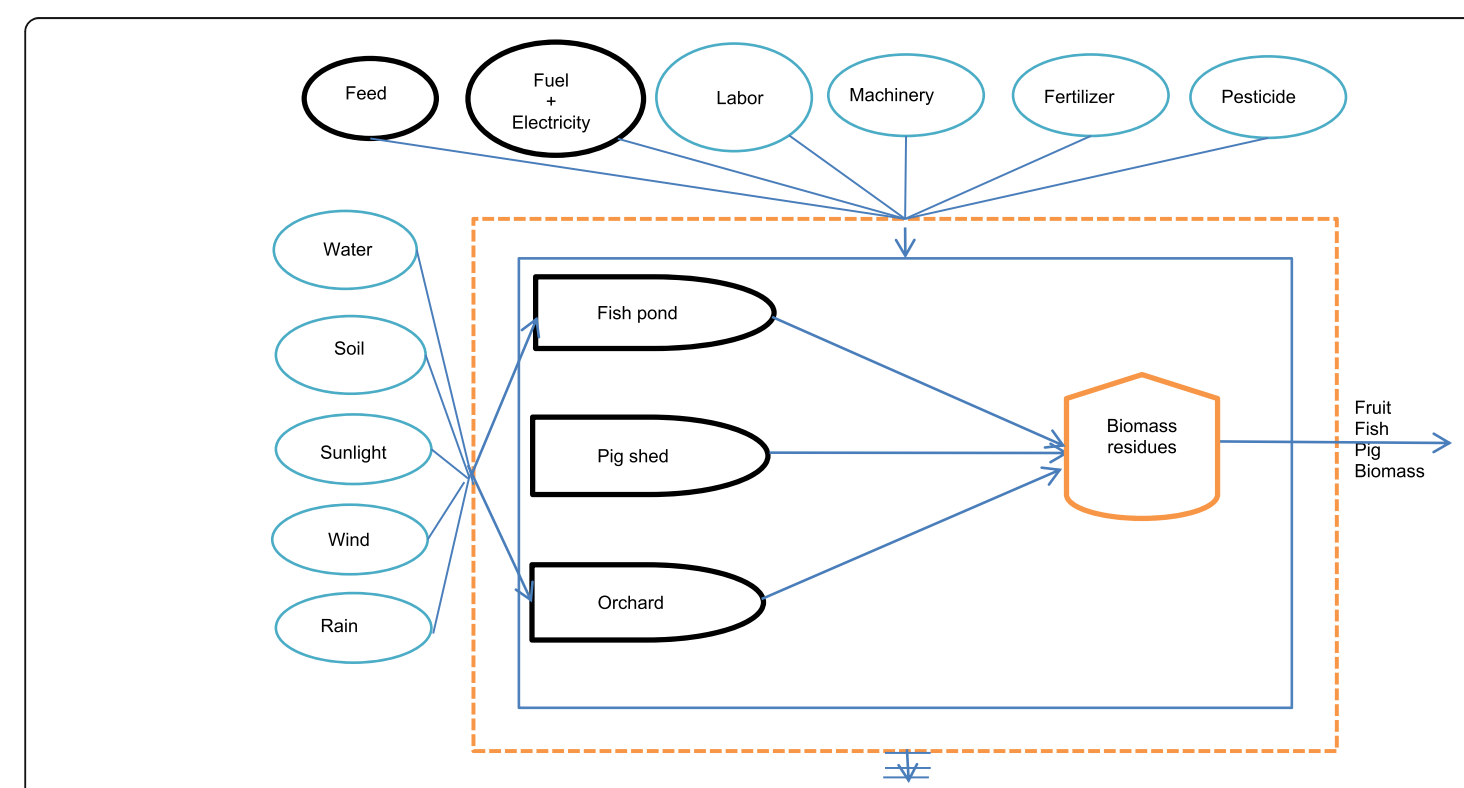

Fig. 3 Material flows of the typical agricultural system on the acid soil area Vietnam 
Table 2 Inputs and yields for system components according to the present farming household system (in a year)

\begin{tabular}{|c|c|c|c|c|c|c|}
\hline Item & Unit & Equivalent factor ( $\mathrm{J}_{\mathrm{ex}} /$ Unit) & Reference & Pig production & Fish production & Orchard \\
\hline \multicolumn{7}{|l|}{ Renewable resource (RR) } \\
\hline Sunlight ${ }^{a}$ & J & $1.02 \mathrm{E}-05$ & {$[11,18,21]$} & $1.17 \mathrm{E}+08$ & $3.26 \mathrm{E}+09$ & $1.63 \mathrm{E}+09$ \\
\hline Wind $^{\mathrm{b}}$ & J & $3.12 \mathrm{E}-02$ & {$[18,21]$} & $7.08 \mathrm{E}+08$ & $1.97 \mathrm{E}+10$ & $9.83 \mathrm{E}+09$ \\
\hline Evapotranspiration $^{c}$ & J & $6.26 \mathrm{E}-01$ & {$[11,18]$} & $1.11 \mathrm{E}+12$ & $3.09 \mathrm{E}+11$ & $1.55 \mathrm{E}+11$ \\
\hline \multicolumn{7}{|c|}{ Natural non-renewable resources (NR) } \\
\hline Water & $\mathrm{kg}$ & $4.94 \mathrm{E}-03$ & {$[18,37]$} & & $4.94 \mathrm{E}+08$ & $3.84 \mathrm{E}+06$ \\
\hline Ground water & $m^{3}$ & $2.00 E+04$ & [38] & $1.34 \mathrm{E}+09$ & & \\
\hline Loss of topsoil ${ }^{d}$ & $\mathrm{~kg}$ & $4.33 \mathrm{E}+07$ & {$[5,10]$} & & & $2.06 \mathrm{E}+11$ \\
\hline \multicolumn{7}{|c|}{ Purchased non-renewable resources (PN) } \\
\hline Diesel & L & $4.78 \mathrm{E}+07$ & [38] & $1.74 \mathrm{E}+10$ & & \\
\hline Concrete & $\mathrm{kg}$ & $6.35 E+12$ & [12] & $2.08 \mathrm{E}+11$ & & \\
\hline Electricity & kW & $3.60 \mathrm{E}+06$ & {$[18,38]$} & $5.18 \mathrm{E}+11$ & & \\
\hline Weaned piglet & $\mathrm{kg}$ & $2.09 E+06$ & [39] & $1.41 \mathrm{E}+11$ & & \\
\hline Pig feed & $\mathrm{kg}$ & $1.43 \mathrm{E}+07$ & [40] & $3.32 \mathrm{E}+13$ & & \\
\hline Lime $(\mathrm{CaO})$ & $\mathrm{kg}$ & $3.11 \mathrm{E}+06$ & [41] & & $3.04 \mathrm{E}+09$ & 7.09E+ 09 \\
\hline Small fry & $\mathrm{kg}$ & $7.98 \mathrm{E}+06$ & [42] & & $7.98 \mathrm{E}+10$ & \\
\hline Fish feed & $\mathrm{kg}$ & $1.26 \mathrm{E}+07$ & [43] & & $128 . E+14$ & \\
\hline \multicolumn{7}{|l|}{ Fertilizer } \\
\hline$N$ & $\mathrm{~kg}$ & $3.28 \mathrm{E}+01$ & {$[9,44]$} & & & $1.28 \mathrm{E}+11$ \\
\hline$P$ & & $7.52 \mathrm{E}+01$ & & & & \\
\hline K & & $4.56 \mathrm{E}+01$ & & & & \\
\hline Pesticide & $\mathrm{kg}$ & $4.20 E+08$ & [18] & & & $1.26 \mathrm{E}+09$ \\
\hline Plough & $\mathrm{kg}$ & $1.80 \mathrm{E}+08$ & [12] & & & 2.47E+ 11 \\
\hline Sapling & $\mathrm{kg}$ & $1.44 \mathrm{E}+07$ & [18] & & & $9.45 E+08$ \\
\hline \multicolumn{7}{|l|}{ Yield $(Y)$} \\
\hline Porker & $\mathrm{kg}$ & $2.03 \mathrm{E}+07$ & [45] & & & $1.15 E+13$ \\
\hline Fish & $\mathrm{kg}$ & $7.98 \mathrm{E}+06$ & [45] & & & $7.98 \mathrm{E}+12$ \\
\hline Fruit & $\mathrm{kg}$ & $1.89 E+12$ & [18] & & & $2.48 \mathrm{E}+10$ \\
\hline
\end{tabular}

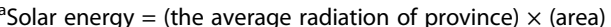

The average radiation of province $=17.5 \mathrm{MJ} /\left(\mathrm{m}^{2}\right.$ day $)=6,387.5 \mathrm{MJ} /\left(\mathrm{m}^{2}\right.$ year $)$

${ }^{\mathrm{b}}$ Global wind circulation $=\left(0.4 \mathrm{~J} / \mathrm{m}^{2} / \mathrm{sec}\right) \times(3.15 \mathrm{E}+7 \mathrm{sec} /$ year $) \times($ area $)$

${ }^{C}$ Evapotranspiration, chemical energy $=($ area $) \times($ average rainfall $) \times($ density $) \times($ Gibbs free energy $)$

Average rainfall $=2 \mathrm{~m} / \mathrm{year}$

Density $=1.00 \mathrm{E}+06 \mathrm{~g} / \mathrm{m}^{3}$

Gibbs free energy $=4.94 \mathrm{~J} / \mathrm{g}$

${ }^{\mathrm{d}}$ Net loss of topsoil $=($ soil loss $) \times($ organic matter content $)=9.5 \mathrm{t} / \mathrm{ha} \times 2.5$ ha

Soil loss $=9.5 \mathrm{t} /$ (ha year)

Organic matter content $=20 \%=0.2$

Natural non-renewable consumed resources include topsoil erosion, groundwater and surface water (which are utilized in horticulture operations) [36]. Many items in this system are purchased non-renewable resources. Inputs and outputs for each component according to the existing farming system are shown in Table 2. The data is divided into groups of both free purchased inputs and the yield referring to outputs. The exergy analysis in the present system is computed for a period of 1 year.

\section{Exergy analysis}

The input and output data sources based on exergetic analysis are shown in Table 2. The items are divided into 3 groups: renewable resources, natural non-renewable resources and purchased-non-renewable resources. As mentioned above, purchased-renewable resources (i.e. labour) are not included in this case. The exergy loss of the whole system and the resource efficiency of each component compared to the entire system are shown in Fig. 4. Most non-renewable natural resources contribute 


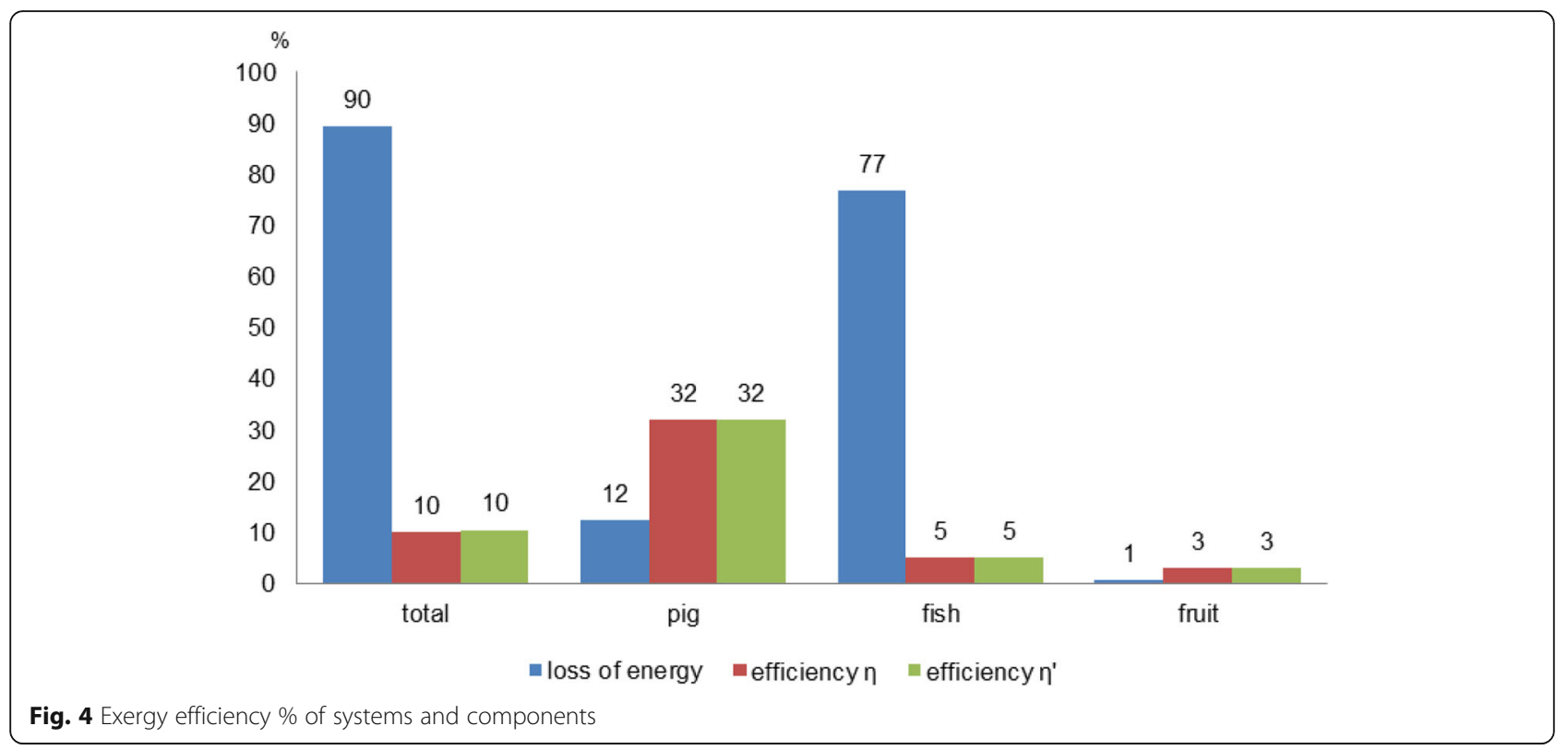

large amounts of exergy to the system, in which the distribution rate of fish feeding accounts for over $80 \%$ of the total input sources. From the total yields of 19 million $\mathrm{MJ}$ in a year, pig and fish production account for about $99 \%$ of the total production with an efficiency rate of $59 \%$ and $41 \%$, respectively. However, the exergy loss from fish production is also the highest among the components. With 195 million MJ per year of exergy content of the total inputs, the exergy loss from the system is significant, accounting for $90 \%$ total inputs. The losses mainly occur in fish production. However, because in the current system three components are operated separately, we consider the calculation of the exergy embodied in each component to identify the main cause of the exergy loss. About $70 \%$ of the exergy loss is generated from pig farming, excluding consideration of pig waste. Likewise, the exergy content in the fishpond is mainly embodied in animal feeding; the fish processing causes a considerable amount of exergy loss. About 95\% of the embodied exergy is lost while fish feeding accounts for over $99 \%$ of the total inputs. Although the rate of exergy loss from the orchard is negligible compared to the entire system, the efficiency from cultivation is only $2 \%$ excluding biomass residues (accounting for $98 \%$ of exergy loss in this process). It is possible to attribute the causes of the exergy loss in the cultivation process to the topsoil loss (over $50 \%$ of the inputs), and the other ones stemming from fertilizer and machinery (plough). The high exergy loss causes the exergy efficiency of the processes to be at a low level. The negligible ratio of waste/by-products to products of each component leads the $\eta$ and $\eta^{\prime}$ values to be almost equivalent (shown in Figs. 4 and 5).
Figure 5 shows the energy flows for the current farm household system. Considering the exergy loss in the current system, the comparison of input and output in the exergy analysis reveals numerous disparities; most of the energy loss is due to fish production. The components of the system process operate individually; thus, there are no links between input and output flows from one component to the others. For each component, the exergy loss from pig production, fish production and orchard is $68 \%, 95 \%$ and $98 \%$, respectively. The exergy efficiency is relatively low with the greatest contributor attributed to pig production at $32 \%$, and fishery and orchard efficiencies at less than $\sim 5 \%$.

The exergy embodied in waste technically contributes to the increase in resource efficiency when it is considered the by-product. The composition of agricultural wastes is mainly organic matters having great potential for recycling. Compared with the negligible energy from biomass residues $(3000 \mathrm{MJ} /$ year) the energy content in pig manure is several times higher $(900,000 \mathrm{MJ} /$ year). Further, the energy content of the released biogas amounts to nominally 1 million MJ/year (a significant consideration).

\section{Applied agricultural zero emission system for the farm}

In a zero emission agricultural system, aquatic plants such as water hyacinth (an indigenous plant species) can be grown in ponds to contribute to bio-treating of wastewater [46]. Water from such a pond can be utilized for irrigating orchards and supplying fishponds (without additional treatment) [47]. Of note, the current system must augment pumped river water with lime. Additionally, aquatic plants may be used to compost and fertilize the garden. Similarly, waste from a pigsty (pig manure + 


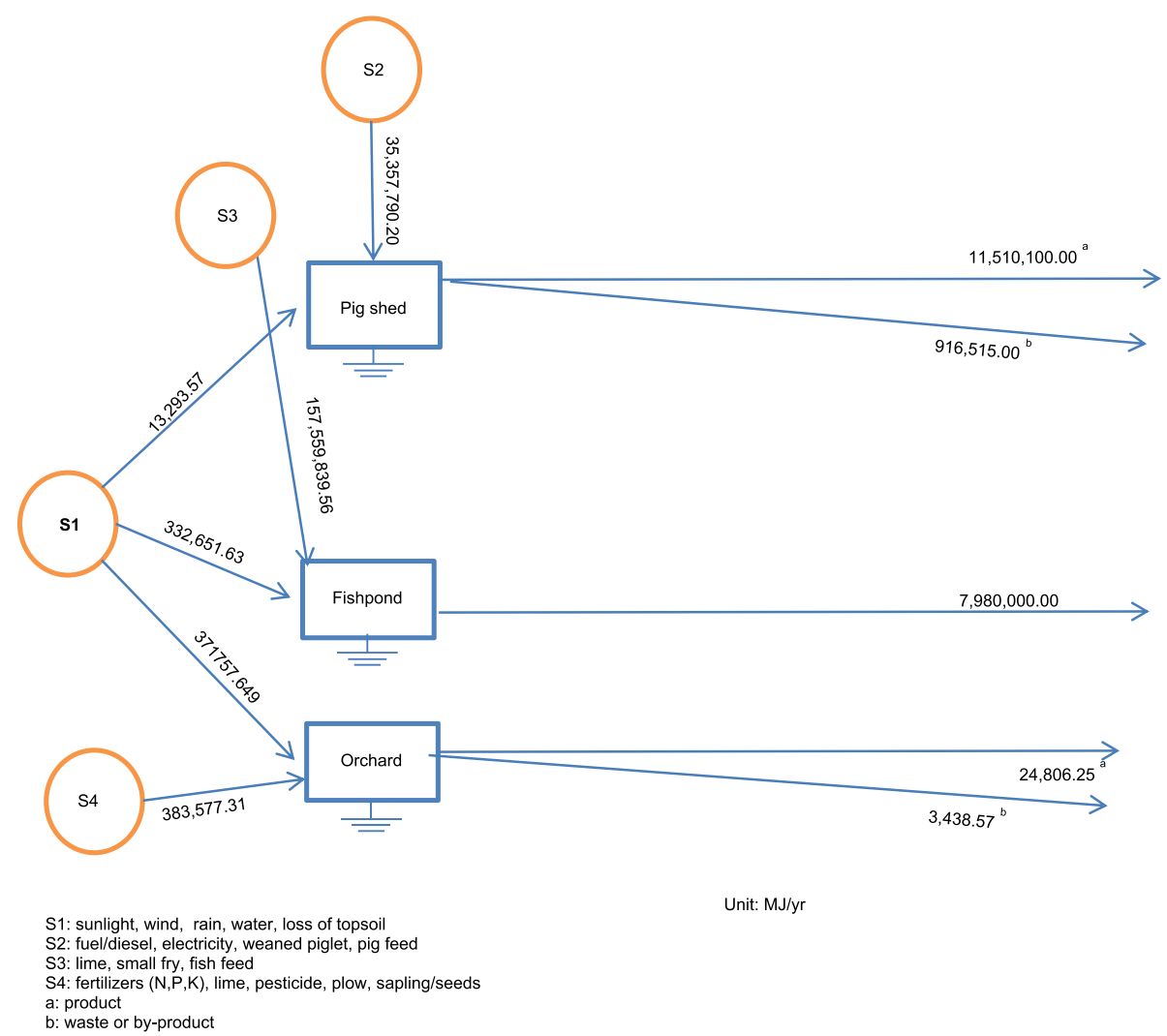

Fig. 5 Embodied exergy flows in MJ/year in agricultural production system in the study area

urine) can be digested in biogas plastic container(s) to create biogas which can be used as an energy source for producing electricity and heat [48]. The pig sludge is used as compost in combination with water hyacinth for pond water treatment and as fertilizer for the orchard. With a $\mathrm{pH}$ level lower than 5 in an acid sulphatecontaining soil [49], resources in the system need to be fully utilized to improve both soil and water quality, while reducing costs for the farm.

Other components that need to be provided in support of the agricultural zero emission system include local plants such as spinach and/or water hyacinth; an aquatic pond; and, plastic containers for biogas production, as presented in Table 3. An aquatic pond can act as storage of sludge from biogas digesters. Floating plants (spinach and water hyacinth) in the pond function as a natural waste filtration system. These kinds of plants, combined with pig sludge, can increase the $\mathrm{pH}$ level of the water and allow water to be used for irrigating plants without further treatment or lime supplementation. Pig manure can be digested in plastic biogas containers. Biogas and sludge generated during the digestion can benefit all components. Sludge is used as bio-fertilizer and fish feed. Pig sludge is mixed with commercial fish feed with a weight ratio of 1: 1 . Simultaneously, biogas can provide heat and electricity for the whole system when using biogas-based generators. The household may no longer need to buy fuel and pay for purchased electricity.

The exergy loss in both current and ideal systems is calculated to be up to $80 \%$ (Fig. 6), leading to low exergy efficiency with $10 \%$ of the current system and about $16 \%$ of the ideal system. However, for the proposed system, the circulation of reused waste linking all components can reduce the loss of embodied exergy in pig and fish production. Taheri et al. imply that a process with higher temperature will result in a reduction of exergy loss [12]. The process of digesting pig slurry produces heat at very high temperatures achieving high exergy efficiency. Other productive processes in the system occur under conditions of ambient temperature, i.e. orchard and pigsty. The causes of heat loss from these components need to be investigated.

Figure 7 shows the energy flows in an idealized system, compared to the current system presuming the case of constant output. Biogas is used as a substitute for electricity and diesel to illuminate the pigsty. With elimination of incandescent lighting fixtures, it is estimated that ten LED light bulbs with a power consumption of $0.018 \mathrm{~kW}$ per bulb (with approximately $150 \mathrm{~h}$ of duty usage) in the current system only requires $324 \mathrm{~kW}$ per year (equivalent 
Table 3 Supplement items for a zero emission system

\begin{tabular}{|c|c|c|c|c|}
\hline Item & Unit & Equivalent factor (J/Unit) & Reference & Total \\
\hline \multicolumn{5}{|c|}{ Natural non-renewable resource (NR) } \\
\hline Water & $\mathrm{kg}$ & $4.94 \mathrm{E}-03$ & {$[18,37]$} & $49.40 E+06$ \\
\hline \multicolumn{5}{|c|}{ Purchased -non-renewable resource (PN) } \\
\hline Plastic & $\mathrm{kg}$ & $1.08 \mathrm{E}+08$ & [12] & $2.80 E+12$ \\
\hline Biogas sludge & $\mathrm{kg}$ & $3.72 E+05$ & [14] & $1.25 E+12$ \\
\hline Biomass (crop residues) & $\mathrm{kg}$ & $1.88 \mathrm{E}+07$ & [44] & $9.13 E+08$ \\
\hline Biogas & $m^{3}$ & $2.20 E+07$ & [38] & $1.95 E+12$ \\
\hline
\end{tabular}

to $1166 \mathrm{MJ}$ per year). This allows for an average consumption of $62 \mathrm{~kW}$ for other household electrical appliances. The remaining approximately 1.4 Million MJ/year of embodied exergy of biogas can be converted into electricity. This surplus can be returned to the local power grid (and refunded to the farmer) or distributed locally. Additionally, surplus biogas can be stored and/or distributed to surrounding households or consumers.

The embodied exergy of biogas sludge is 65 times lower than that of commercial fish feeds. Thus, replacing commercial fish feed by addition of sludge the embodied exergy in the system can considerably reduce aquatic farming costs. Farming experience showed that sludge supplemented with fish feed at a weight ratio of 1:1 (equal to 78 million $\mathrm{MJ} /$ year in feed and 1 million $\mathrm{MJ} /$ year in sludge) leads to the same fish yield as supplying only commercial feed. Energy input in the sludge/commercial feed combination amounts to only half the energy for fish feeding compared to the present system. However, empirical measures are needed for analysing and formulating the complete fish diets using locally available ingredients to optimize fish growth and health [50].

For orchard inputs, the recycled waste consists of jackfruit leaf and pig sludge waste (crude protein content is
$12.8 \%$ and $2 \%$, respectively). It is possible to combine the orchard wastes with local plants (spinach and water hyacinth with $0.5 \%$ protein) to form biochar. This biochar contains the embodied exergy from biomass residues and sludge $(900 \mathrm{MJ} /$ year and 450,000 MJ/year, respectively), which can meet the nitrogen needs of the plants.

For the evaluation of a zero emission system, one can evaluate waste recycling and utilization of locally available resources to create closed material loops. Based on this analysis, power contribution of human resources will be negligible to the power contribution of the processes. Under the assumption of water resources (ground and surface water) seen as non-renewable natural resources, exergy efficiency depends on the allocation of the natural resources [15].

In Table 4, the results of calculating exergy efficiency in a zero emission system vs. the scenario in a current farming system are shown.

Regarding the rankings for sustainability indicators, the RI and ERYR values of this system are comparable to that in Organization for Economic Cooperation and Development (OECD) values. These values resulted from the study of Hoang and Alauddin which present rankings of the seven indicators in 29 OECD countries. In spite of the

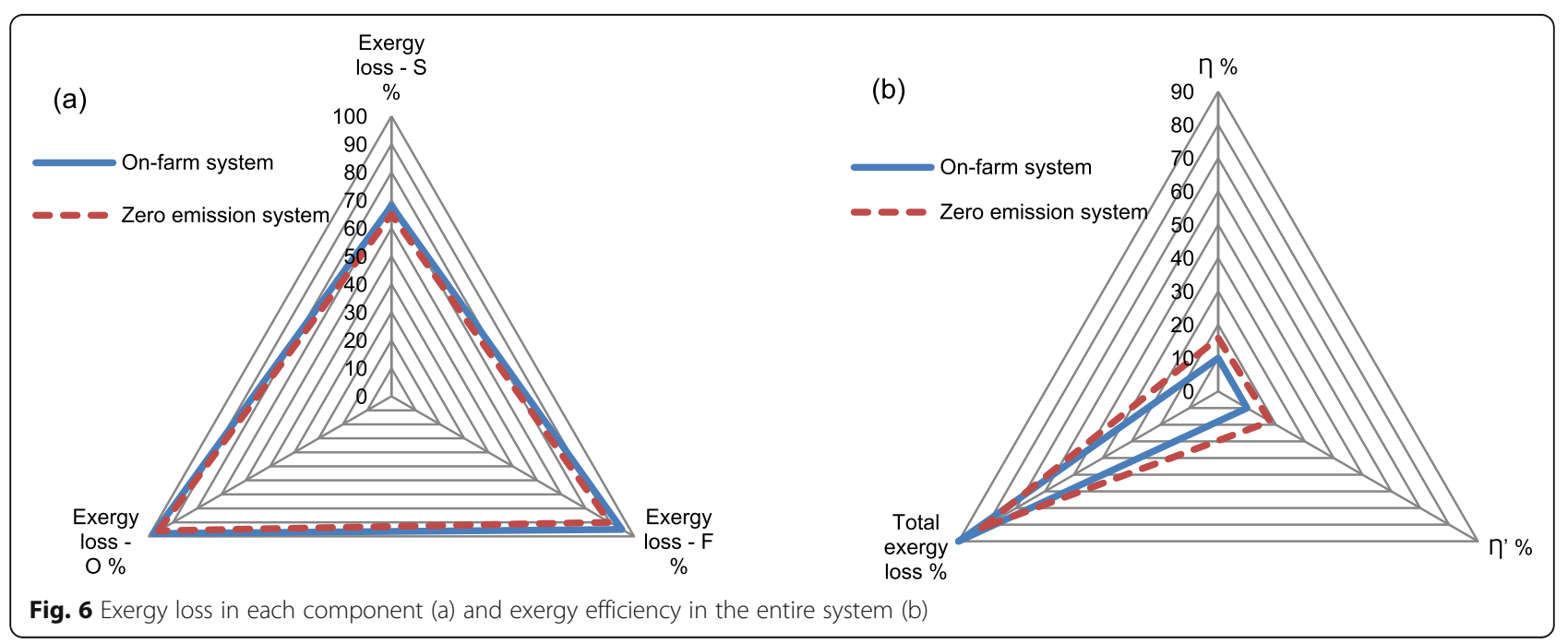




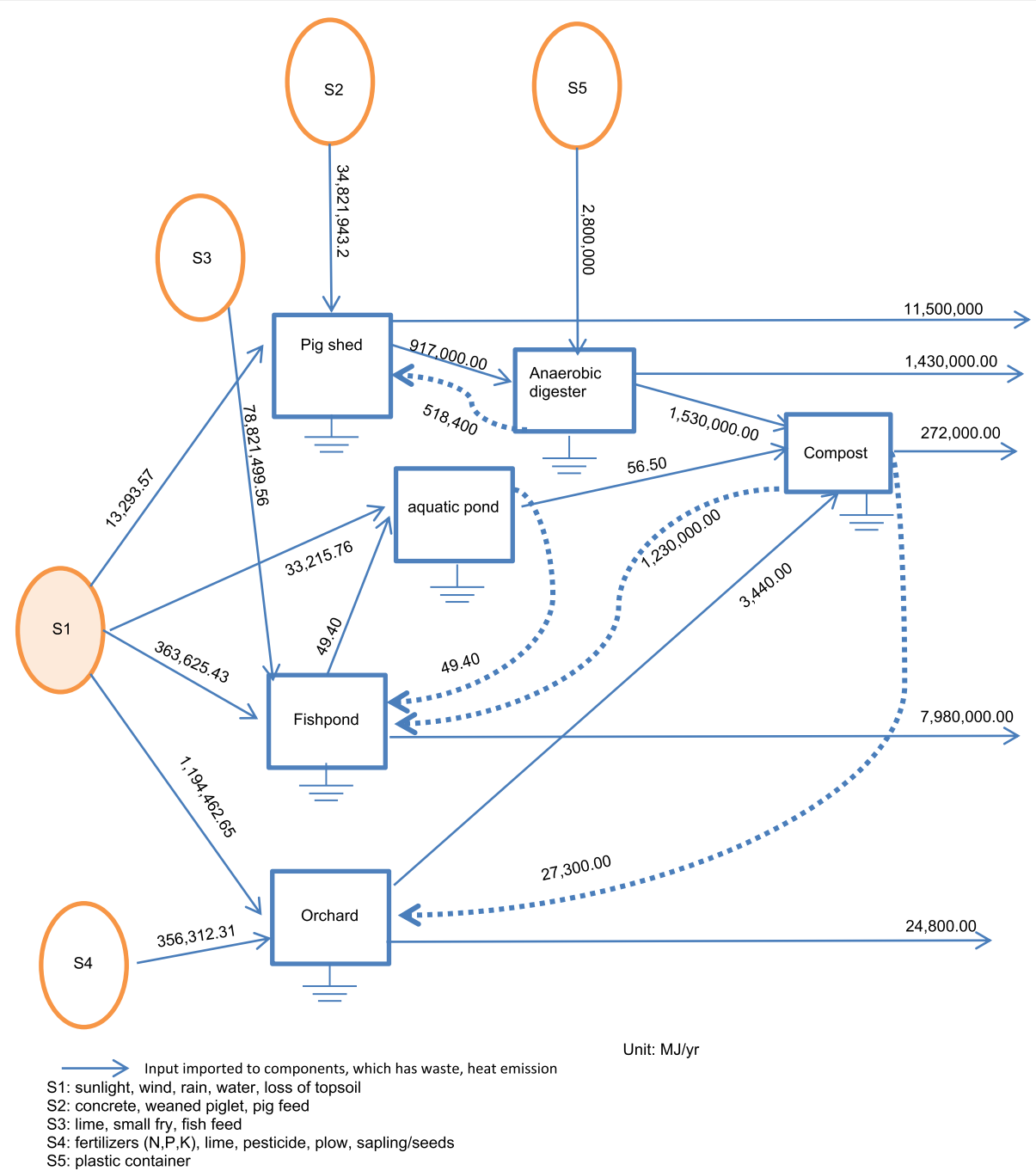

Fig. 7 Energy flows in an idealized agro-ecosystem

variety of range in indicators among the countries, the results showed the stability of NRYR compared to the other indicators [25]. The scenario reduces half of the environmental load; whereas its ELI value is approximately a half lower than that of the present system. Nevertheless, it is

Table 4 Indicators of sustainable agriculture in the current and a zero emission system

\begin{tabular}{lll}
\hline Indicators $^{\text {a }}$ & Current farming system & Zero emission system \\
\hline $\mathrm{RI}$ & 0.002 & $0.009^{*}$ \\
ELI & 125 & $80.3^{*}$ \\
IYR & $10^{*}$ & 12.8 \\
ERYR & 0.08 & $0.2^{*}$ \\
STr & $10^{*}$ & 13 \\
NRYR & $10^{*}$ & 13 \\
\hline
\end{tabular}

*Better

${ }^{\text {a }}$ Reference [25]

For abbreviations see Table 1 significantly higher than all OECD indicator scores. It is concluded that both systems have high investment costs. Other indicators have ten times higher scores compared to the OECD benchmarks. This study concludes that $1 \mathrm{MJ}$ of the outputs needs $10 \mathrm{MJ}$ of the inputs, whereas $1 \mathrm{GJ}$ of the total resources consumed in farming from OECD countries produced $1 \mathrm{GJ}$ of the outputs. The systems imply sustainability of agriculture production by NRYR which is a good indicator of the agriculture sustainability. Hence, it is suggested that the exergy loss in the system process needs to be further investigated. Further considerations may warrant evaluation of effective alternatives to either converting exergy loss products or adjusting the input supplements for the same outputs.

Waste recycling for an integrated agro-ecosystem has positive effects, resolving the problem of waste and environmental pollution by reducing the purchases [51, 52]. Further research will be related to adjusting the 
input items to optimize the utilization of renewable resources from the local ecosystem. The next study step should aim at aggregating the input-output flows (containing waste and heat therein) along with locally available resources over the optimum time when linking the functions of the components within the farming system. The suggestion considers the effectiveness of recyclewaste flows in different directions to produce high-yield in all components.

\section{Conclusion}

Considering integrated systems based on the living conditions of the household, an agro-based industrial zero emissions system (AIZES) is proposed. To optimize the use of renewable energy resources and limit non-renewable consumption, the study suggests a possible agricultural system making use of indigenous, available natural resources towards zero emission. The study employed exergy methods, since the methods allow for calculating material flows only in a single energy unit for assessing resource efficiency at a typical farming system in Vietnam. Based on the current farming system, other components are added to close all input-output flows towards agricultural zero emission system. Biogas digesters and aquatic ponds (with aquatic plants such as spinach and water hyacinth) enhance the benefits of the exergy efficiency in the system. Pig sludge and biomass residues, when utilized, can reduce energy loss. Besides offering a supplement for fish feed, pig sludge can be used as a high efficiency fertilizer when mixed with biomass residues [53]. Additionally, the farming household(s) may be able to replace fuel and electricity resulting in energy selfsufficiency and resale of distributed electricity/fuel (biogas) to the electric authority or surrounding households. Using all OECD indicators for sustainable agriculture through energy measures, the proposed zero emission agricultural system reduces external energy demand and halves the environmental load-thereby reducing environmental pressures considerably.

\section{Abbreviations \\ AIZES: Agro-Industrial Zero Emissions Systems; COREA: Cumulative overall natural resource efficiency; EA: Exergy analysis; EEA: Extended exergy accounting; EROI: Energy return on energy investment; ELI: Environmental loading of investment; ERYR: Ecosystem resource-yield ratio; IYR: Investment- yield ratio; NR: Non-renewable resources; NRYR: Non-renewable yield ratio; OECD: Organization for Economic Cooperation and Development; PN: Purchased non-renewable; PR: Purchased-renewable resources; RI: Renewability Index; RR: Natural renewable resources; STr: System transformity}

\section{Acknowledgements}

The research team would like to thank to the Vietnam Ministry of Science and Technology (MOST) for funding the National key research project KC08.19/16-20, the Department of Natural Resources and Environment (DONRE) in LongAn province for assistance during site investigation and system demonstration and the ASEAN-European Academic University network (ASEA-UNINET) for collaboration with IPPE, TU Graz, Austria, to implement this study. Special thanks to Mr. Mark Looney (Environmental Source Samplers, Inc., Wilmington, NC, mark@essknowsair.com) for your elaborative language editing on our manuscript.

\section{Authors' contributions}

NTTT initiated the research idea and developed the system under supervision of LTH and TVT, and LTH also designed and organized the whole research of this study. NTTT and SLT had a lead role in the literature review and the setup of system. TVT and a group of coworkers at IER were the site engineers who brought the system into application in a household farm at Long An province, Mekong Delta area, VN. NTPT was responsible for the communication with the other partner during the site survey and data acquisition. HS, SB and GB contributed in the research idea development, especially about the exergy efficiency and zero emission application for the system, and they also checked English in the final step. All authors read and approved the final manuscript.

\section{Authors' information}

Le Thanh Hai, Mr., Dr., is a full professor and Director of the Institute for Environment and Resources, VNU-HCM.

Nguyen Thi Thu Thao, Ms, is a PhD candidate (under supervision of Prof. LTH) and a lecturer in the Faculty of Chemical and Food Technology, University of Technology and Education, HCM City, VN.

Tra Van Tung, Mr., Dr., is senior researcher at the Department of Environmental Engineering, Institute for Environment and Resources, VNUHCM.

Nguyen Thi Phuong Thao, Ms, is senior researcher and Vice Head of the Department of Environmental Management, Institute for Environment and Resources, VNU-HCM.

Son Le Thanh, Mr., MSc is a student at the Water and Environmental Engineering programme, Nagasaki University, Japan.

Hans Schnitzer, Mr., Dr., is a professor at the Institute for Process and Particle Engineering, Graz University of Technology, Austria.

Sibylle Braunegg, Mrs., is a senior manager in the StadtLaborGraz, a private research institution in Graz, Austria.

Gerhart Braunegg, Mr., Dr., is a retired professor at the Institute of Biotechnology and Biochemical Engineering, Graz University of Technology, Austria, and lead researcher of ARENA, a private research institution.

\section{Funding}

This research is funded by the Vietnam Ministry of Science and Technology (MOST) under the grant number KC08.19/16-20.

\section{Availability of data and materials}

The main datasets on which the results of the manuscript based are presented in the main paper.

Ethics approval and consent to participate

Not applicable.

\section{Consent for publication}

Not applicable.

\section{Competing interests}

The authors declare that they have no competing interests.

\section{Author details}

${ }^{1}$ Institute for Environment and Resources, National University of Ho Chi Minh City, Ho Chi Minh 740500, Vietnam. ${ }^{2}$ Faculty of Chemical and Food Technology, Ho Chi Minh City University of Technology and Education, Ho Chi Minh, Vietnam. ${ }^{3}$ Institute for Process and Particle Engineering, Graz University of Technology, A-8010 Graz, Austria. ${ }^{4}$ Water and Environmental Engineering, Nagasaki University, Nagasaki 852-8521, Japan. ${ }^{5}$ ARENA Research for Sustainable Resources, A-8010 Graz, Austria. ${ }^{6}$ StadtLABOR-Innovations for Urban Quality of Life, Graz, Austria. 
Received: 4 February 2020 Accepted: 20 August 2020 Published online: 21 September 2020

\section{References}

1. Amir Neori, Muki Shpigel Lior Guttman, Alvaro. Israel Development of Polyculture and Integrated Multi Trophic Aquaculture (IMTA) in Israel: a review. The Israeli Journal of Aquaculture - Bamidgeh. IJA-69.2017.1385. p. 19.

2. N. Van Huong, T. Huu Cuong, T. Thi Nang Thu, and P. Lebailly (2018) Efficiency of different integrated agriculture aquaculture systems in the Red River Delta of Vietnam. Sustainability 10:doi: https://doi.org/10.3390/ su10020493

3. J. Gołaszewski et al.(2012) Energy saving measures in agriculture - overview on the basis of national reports

4. Marcos Vinícius Eloy Xavier, Andrea Marcello Bassi, Cibele Mally de Souza, Wilson Pereira Barbosa Filho, Kevin Schleiss and Felipe Nunes (2013) Energy scenarios for the Minas Gerais State in Brazil: an integrated modeling exercise using System Dynamics. Sustainability and Society 2013

5. Vigne M, Vayssieres J, Lecomte P, Peyearaud JL (2012) Evaluating the ability of current energy use assessment methods to study contrasting livestock production systems. J Environ Manage 112:199-212. https://doi.org/10.1016/ j.jenvman.2012.07.017

6. G. T. Tucho and S. Nonhebel (2017) Alternative energy supply system to a rural village in Ethiopia. Energy, Sustainability and Society 7:doi: 10.1186/ s13705-017-0136-x

7. Anke Bischoff (2012) Insights to the internal sphere of influence of peasant family farms in using biogas plants as part of sustainable development in rural areas of Germany. Bischoff Energy, Sustainability and Societ

8. J. Daniel-Gromke, J. Liebetrau, V. Denysenko, and C. Krebs (2015) Digestion of bio-waste - GHG emissions and mitigation potential. Energy, Sustainability and Society 5:doi: 10.1186/s13705-014-0032-6

9. R. Muvhiiwa, D. Hildebrandt, N. Chimwani, L. Ngubevana, and T. Matambo (2017) The impact and challenges of sustainable biogas implementation: moving towards a bio-based economy. Energy, Sustainability and Society 7: doi: 10.1186/s13705-017-0122-3

10. H. E. Kelebe (2018) Returns, setbacks, and future prospects of bio-energy promotion in northern Ethiopia: the case of family-sized biogas energy. Energy, Sustainability and Society 8:doi: 10.1186/s13705-018-0171-2

11. Yang J, Chen B (2014) Emergy analysis of a biogas-linked agricultural system in rural China - a case study in Gongcheng Yao Autonomous County. Applied Energy 118:173-182. https://doi.org/10.1016/j.apenergy.2013.12.038

12. Zhang L, Wang C (2014) Energy and GHG analysis of rural household biogas systems in China. Energies 7:767-784. https://doi.org/10.3390/en7020767

13. Perryman ME, Schramski JR (2015) Evaluating the relationship between natural resource management and agriculture using embodied energy and eco-exergy analyses: a comparative study of nine countries. Ecological Complexity 22:152-161. https://doi.org/10.1016/j.ecocom.2015.04.002

14. Smith LG, Williams AG, Pearce BD (2014) The energy efficiency of organic agriculture: a review. Renewable Agriculture and Food Systems 30:280-301. https://doi.org/10.1017/s1742170513000471

15. J. L. Wightman and P. B. Woodbury (2019) Maximizing social benefit from finite energy resource allocation. Energy, Sustainability and Society 9:doi: 10. 1186/s13705-019-0208-1

16. S. Maier, M. Szerencsits, and K. Shahzad (2017) Ecological evaluation of biogas from catch crops with Sustainable Process Index (SPI). Energy, Sustainability and Society 7:doi: 10.1186/s13705-017-0106-3

17. Chen ZM, Chen B, Chen GQ (2011) Cosmic exergy based ecological assessment for a wetland in Beijing. Ecological Modelling 222:322-329. https://doi.org/10.1016/j.ecolmodel.2010.09.023

18. B. Guo, X. Yang, X. Jin, and Y. Zhou (2015) Eco-exergy-based ecological flow accounting of cropland ecosystem and utilisation efficiencies in China. International Journal of Exergy 17:doi: 10.1504/ijex.2015.069319

19. Huysveld, S. (2016) Exergy-based natural resource accounting in sustainability assessment of agricultural production systems. PhD Thesis. Ghent University, Belgium.

20. Jørgensen SE, Nielsen SN (2014) Use of eco-exergy in ecological networks. Ecological Modelling 293:202-209. https://doi.org/10.1016/j.ecolmodel.2014. 05.007

21. Liu Z et al (2017) Cosmic exergy-based ecological assessment for farmlanddairy-biogas agroecosystems in North China. Journal of Cleaner Production 159:317-325. https://doi.org/10.1016/j.jclepro.2017.05.056
22. Sciubba $E$ (2003) Cost analysis of energy conversion systems via a novel resource-based quantifier. Energy 28:457-477. https://doi.org/10.1016/s03605442(02)00096-8

23. Taheri K, Gadow R, Killinger A (2014) Exergy analysis as a developed concept of energy efficiency optimized processes: the case of thermal spray processes. Procedia CIRP 17:511-516. https://doi.org/10.1016/j.procir.2014.01.060

24. Kriechbaum L, Scheiber G, Kienberger T (2018) Grid-based multi-energy systems - modelling, assessment, open source modelling frameworks and challenges nergy. Sustainability and Society. https://doi.org/10.1186/s13705018-0176-X

25. Hoang V-N, Alauddin M (2011) Analysis of agricultural sustainability: a review of exergy methodologies and their application in OECD countries. International Journal of Energy Research 35:459-476. https://doi.org/10. 1002/er.1713

26. Zhang B, Jin P, Qiao H, Hayat T, Alsaedi A, Ahmad B (2019) Exergy analysis of Chinese agriculture. Ecological Indicators 105:279-291

27. Budak G, Chen X, Celik S, Ozturk B (2019) A systematic approach for assessment of renewable energy using analytic hierarchy process. Energy, Sustainability and Society 9:37. https://doi.org/10.1186/s13705019-0219-y

28. Gurung T (2012) Integrated aquaculture within agriculture irrigation for food security and adaptation to climate change. Hydro Nepal: Journal of Water, Energy and Environment 11(1):73-77. https://doi.org/10.3126/hn.v11i1.7214

29. T. H. Le, V. T. Tran, Q. V. Le, T. P. T. Nguyen, H. Schnitzer, and G. Braunegg (2016) An integrated ecosystem incorporating renewable energy leading to pollution reduction for sustainable development of craft villages in rural area: a case study at sedge mats village in Mekong Delta, Vietnam. Energy, Sustainability and Society 6:doi: 10.1186/s13705-016-0088-6

30. Sciubba E (2003) Extended exergy accounting applied to energy recovery from waste: The concept of total recycling. Energy 28:1315-1334. https:// doi.org/10.1016/s0360-5442(03)00111-7

31. N. Fatima, Y. Li, M. Ahmad, G. Jabeen, and X. Li (2019) Analyzing long-term empirical interactions between renewable energy generation, energy use, human capital, and economic performance in Pakistan. Energy, Sustainability and Society 9:doi: 10.1186/s13705-019-0228-x

32. Maier S, Gemenetzi A (2014) Optimal renewable energy systems for industries in rural regions. Energ Sustain Soc 4:9. https://doi.org/10.1186/ 2192-0567-4-9

33. Terzi R (2018) "Application of Exergy Analysis to Energy Systems," in Application of Exergy

34. Rocco MV, Colombo E, Sciubba E (2014) Advances in exergy analysis: a novel assessment of the Extended Exergy Accounting method. Applied Energy 113:1405-1420. https://doi.org/10.1016/j.apenergy.2013.08.080

35. Sciubba E (2001) Beyond thermoeconomics? The concept of Extended Exergy Accounting and its application to the analysis and design of thermal systems. Exergy Int. J. 1(2):68-84

36. Grunwald A, Rösch C (2011) Sustainability assessment of energy technologies: towards an integrative framework. Energ Sustain Soc 1:3. https://doi.org/10.1186/2192-0567-1-3

37. Brown MT, Ulgiati S (2004) Emergy analysis and environmental accounting. Encyclopedia of energy volume 2

38. Phan Hieu Hien (2015) Energy in agricluture. Agriculture publishing house (AP), Vietnam

39. Ramirez C, Patel M, Blok K (2006) How much energy to process one pound of meat? A comparison of energy use and specific energy consumption in the meat industry of four European countries. Energy 31:2047-2063. https:// doi.org/10.1016/j.energy.2005.08.007

40. Dung NNX, Manh LH, Thao HTP (2004) Effects of protein and energy levels on performance of piglets to weaning. Can Tho University, Journal of Science 2004(1):8-17

41. Taner T, Sivrioglu M (2017) A lime production of the fluidized bed boiler's energy and exergy analyse. Journal of Thermal Engineering 3(3):1271-1274

42. Bud I, Ladosi Daniela, Reka ST., Negrea O. (2008) Study concerning chemical composition of fish meat depending on the considered fish species. Lucrări ştiinŃifice Zootehnie şi Biotehnologii, vol. 41 (2).

43. TOdum H.T. (2002) Emergy accounting. In: Bartelmus P (ed) Unveiling wealth. Springer, Dordrecht. https://doi.org/10.1007/0-306-48221-5_13

44. Akter MS, Ershaduzzaman M, Talukder MAl, Ali MY, Rahman MZ (2016) Effect of feeding tree forages on productive performances on growing sheep. Asian Journal of Medical and Biological Research 1:648-653. https://doi.org/ 10.3329/ajmbr.v1i3.26489 
45. Jorgensen SE, Odum HT, Brown MT (2004) Emergy and exergy stored in genetic information. Ecological Modelling 178:11-16. https://doi.org/10. 1016/j.ecolmodel.2003.12.036

46. Simon Goddek, Alyssa Joyce, Benz Kotzen, Gavin M. Burnell (2019) Aquaponics food production systems. Springer open. doi: https://doi.org/10. 1007/978-3-030-15943-6.

47. Patrick Dugan, Madan Dey and V. V. Sugunan (2004) Fisheries and water productivity in tropical river basins: enhancing food security and livelihoods by managing water for fish. In: Proceedings of the 4th International Crop Science Congress, 26 Sep - 1 Oct 2004, Australia.

48. R. P. van Leeuwen, J. Fink, J. B. de Wit, and G. J. M. Smit (2015) Upscaling a district heating system based on biogas cogeneration and heat pumps. Energy, Sustainability and Society 5:doi: 10.1186/s13705-015-0044-x

49. Cho K.M., Ranamukhaarachchi S.L. and Zoebisch M.A. (2002) Cropping systems on acid sulphate soils in the central plains of Thailand: constraints and remedies. Paper presented at 17th WCSS, 14-21 August 2002, Thailand.

50. Suloma A, Ogata HY (2006) Review: future of rice-fish culture, desert aquaculture and feed development in Africa: the case of Egypt as the leading country in Africa. JARQ 40(4):351-360 http://www.jircas.affrc.go.jp

51. A. D. Zajdband, "Integrated agri-aquaculture systems," in Genetics, biofuels and local farming systems (Sustainable Agriculture Reviews, 2011, pp. 87-127.

52. Rawlinson, Peter (2002) Increasing water use efficiency through integrated agri-aquaculture. In: Proceedings of the Eleventh Biennial Conference of the International Institute of Fisheries Economics and Trade, Auqust 19-22, 2002, Wellington, New Zealand.

53. Nielsen AH, Kristensen IS (2005) Nitrogen and phosphorus surpluses on Danish dairy and pig farms in relation to farm characteristics. Livestock Production Science 96:97-107. https:/doi.org/10.1016/j.livprodsci.2005.05.012

\section{Publisher's Note}

Springer Nature remains neutral with regard to jurisdictional claims in published maps and institutional affiliations.

Ready to submit your research? Choose BMC and benefit from:

- fast, convenient online submission

- thorough peer review by experienced researchers in your field

- rapid publication on acceptance

- support for research data, including large and complex data types

- gold Open Access which fosters wider collaboration and increased citations

- maximum visibility for your research: over $100 \mathrm{M}$ website views per year

At $\mathrm{BMC}$, research is always in progress.

Learn more biomedcentral.com/submissions 